CAHIERS

MONDES

ANCIENS

\section{Cahiers « Mondes anciens »}

Histoire et anthropologie des mondes anciens

$13 \mid 2020$

Qu'est-ce que faire école? Regards sur « l'école de

Paris »

\title{
École de Paris. Praising or Debasing an Approach to the Study of Greek Sacrifice
}

École de Paris. Louer ou écarter une forme d'étude du sacrifice grec

\section{Gunnel Ekroth}

\section{(2) OpenEdition}

\section{Journals}

Electronic version

URL: http://journals.openedition.org/mondesanciens/2764

DOI: $10.4000 /$ mondesanciens. 2764

ISSN: 2107-0199

\section{Publisher}

UMR 8210 Anthropologie et Histoire des Mondes Antiques

Electronic reference

Gunnel Ekroth, «École de Paris. Praising or Debasing an Approach to the Study of Greek Sacrifice ». Cahiers « Mondes anciens » [Online], 13 | 2020, Online since 10 June 2020, connection on 12 June 2020. URL : http://journals.openedition.org/mondesanciens/2764 ; DOI : https://doi.org/10.4000/ mondesanciens. 2764

This text was automatically generated on 12 June 2020 .

\section{cc) $(1) \odot$}

Les Cahiers «Mondes Anciens » sont mis à disposition selon les termes de la licence Creative Commons Attribution - Pas d'Utilisation Commerciale - Pas de Modification 4.0 International. 


\section{École de Paris. Praising or Debasing an Approach to the Study of Greek Sacrifice}

École de Paris. Louer ou écarter une forme d'étude du sacrifice grec

Gunnel Ekroth

1 The denomination "school" in academic contexts carries with it a certain ambiguity. ${ }^{1}$ On the one hand, a school can designate a vibrant, stimulating and innovative environment, where the synergy created by its members results both in new perspectives on method and theory and in groundbreaking empirical results, and a transferal of this knowledge and traditions from one generation to the next. On the other hand, a school can refer to an academic setting, which is closed, somewhat selfsufficient, almost complacent and more concerned with preserving its own culture and worldview than promoting new ways of thinking. From this starting point, my contribution will reflect on the impact of the notion École de Paris or Paris School within the field of Anglophone research on Greek religion and especially on sacrifice. ${ }^{2}$ How has the concept of a "Paris school" been handled within the study of Greek religion and what position does it occupy for scholars working in this field? Is it the model or theoretical approach to actively adopt or reject, or is it more of a label referred to in passing to position oneself without a more close engagement?

2 The obvious point of departure is 1979, the year the volume La cuisine du sacrifice en pays grec was published, which contained nine papers as well as an extensive bibliography on publications dealing with sacrificial ritual. When it first appeared, only a small number of Anglophone journals reviewed La cuisine du sacrifice and the judgement was mixed. Richard Buxton called it "a forceful statement of one particular view of Greek sacrificial ritual". ${ }^{3}$ The book also received a favorable judgement in an English review article of recent French research in the history of religions published in $1982 .{ }^{4}$ The author was, however, a French historian of religion at the Sorbonne, perhaps more likely to be open to structuralist approaches, although even he found the analysis of the subject slightly too abstract and intellectualizing, considering the fact that sacrifice 
was a religious experience lived in everyday life. A considerably more critical stance was taken by John Pollard in the Journal of Hellenic Studies in 1981, who was largely negative and dismissive, almost condescending, especially of how the text was written, a position, which may partly depend on him describing sacrifice as "in many ways a distasteful subject". ${ }^{5} \mathrm{He}$ also characterized the writing as a "highly abstract verbiage", which he found to verge on the mystical and hard to follow, although he was pleased that the volume was illustrated.

3 The English translation by Paula Wissing, The cuisine of sacrifice among the Greeks, which appeared in 1989, seems to have caused even less reaction among Anglophone reviewers. The only instance I have found is by a theologian, Paul Corby Finney, who found the book "informative and well-executed volume" and, perhaps surprising for a contemporary reader, an "excellent background reading for the study of early Christianity", although marred by "some unwelcome structuralist jargon". ${ }^{6}$

4 One reason for the scarcity of reviews in English journals dealing with Classical antiquity may have been that La cuisine was seen more as an anthropological study than a purely classicist one. Another was apparently language, especially French language, and the influence of the Cuisine of sacrifice on scholarship on Greek religion was only really felt after the English translation in 1989. The difference in impact before and after the translation into English can in a sense be compared with the effects of the works of Walter Burkert. It took eleven years for Homo necans to appear in English in 1983 and the German original version was not reviewed in any major Anglophone journal. ${ }^{7}$ Greek religion, now a standard work for any student in the field, was published in English in 1985, eight years after the German original came out. ${ }^{8}$ In the case of the Cuisine of sacrifice, one wonders if language itself posed the main problem or if the intellectual approach and its novelty was an additional complication.

\section{What's in a Name?}

5 From 1989 until today, there has been a growing interest in Greek animal sacrifice among scholars writing in English. A closer look at major studies and handbooks primarily from the last ten years dealing with the topic will provide a case study of how the concept 'Paris school' has been treated. ${ }^{9}$ I make no claim to have considered every publication in the field mentioning the École.

6 It is obvious that any study dealing with animal sacrifice in Greek antiquity has to relate to the Paris school, whether or not this particular term is used. In fact, the terminology is far from consistent. 'Paris school' is the denomination most frequently found, sometimes specified as the 'so-called Paris school', but also the term 'French school' is encountered, as well as the 'Paris-Lausanne school' or even the 'Vernant school' as well as 'École the Paris' and École de Paris (used in the same scholarly work). An early (or even the earliest?) use of the school concept appears in Richard Buxton's introduction to a collection of structuralist essays edited by Richard Gordon in 1981, where he spoke of Detienne, Vernant and Vidal-Naquet as forming a 'school' with the magisterial Vernant as its head..$^{10}$ The variations as to denominations are to some extent related to the fact that the concept 'École de Paris' or 'Paris school' has never been used by its own members to designate themselves, their publications or their scholarly approach. Pierre Vidal-Naquet, in an article in The Columbia history of twentieth-century French thought (2006), considered the term "the Paris school of Greek 
studies" foremost as the American understanding of the members of the Centre Louis Gernet. ${ }^{11}$ On the other hand, the notion that the works produced by this particular group of scholars was a joint effort is prominent in their own writings, even in the works of Jean-Pierre Vernant, whether or not a particular school label has been applied by themselves. ${ }^{12}$

\section{One School, Many Positions}

7 If we now proceed to how the concept of a 'Paris school' has been handled within the study of Greek religion, the image is far from uniform. Four somewhat overlapping positions can be distinguished: (1) scholars naming the Paris school as a theoretical approach, and subsequently using and interacting with this framework, (2) critiques of the concept Paris school and its contents, which is also a form of interaction, (3) the naming and referring to the Paris school in passing, mainly as a model one has to mention but does not necessarily engage with in any depth, and finally, (4) studies on Greek sacrifice which do not use the term or comment on the Paris school.

Sarah Peirce's important paper on sacrificial iconography from 1993 is one of the earliest examples of a full engagement with the theoretical model by the Paris school, or as she labels it as well, the Paris-Lausanne school. ${ }^{13}$ She lays out the similarities of her method to that of the Paris school; to read the images like a language and consider the entire repertoire of the motif as the foundation for the conclusions, but contrary to the structuralist approach, she considers the impact of different workshops and iconographic developments. Peirce also discusses the Paris school in relation to Walter Burkert's model, a comparison that will later be made by many scholars. Her conclusion is that the iconography of thysia does not aim at hiding violence and instead should be seen as a visual metaphor for joy and festivity. Peirce is in fact one of the few scholars working on Greek sacrifice who fully interacts with the Paris school model, both testing and developing it, and in this process, she reaches a new and, in my opinion, more comprehensive understanding of the iconographic evidence for animal sacrifice.

In her study of animal sacrifice in ancient Greece, Judaism and Christianity from 2008, Maria-Zoe Petropoulou, in her chapter on approaches, presents the views of what she labels variously the Vernant school, the French structuralist school, the French school as well as the Paris school. ${ }^{14}$ She is initially quite dismissive due to the selective empirical foundation of the theoretical framework, even singling out a paper by François Poplin on the uses of animals in religious practices as "a bad example of the French school of thought" due to the evidence being gathered in an unsystematic manner including sources of different date, location and disciplines. ${ }^{15}$ In the end, however, Petropoulou declares her affinity for structuralist approaches to the study of ancient sacrifice. ${ }^{16}$

10 Fred Naiden's work constitutes perhaps the most explicit critique of the sacrificial theories of the Paris school and both Jean-Pierre Vernant and Marcel Detienne, but by criticizing these scholars, he explicitly engages with their work and finds it central to our understanding of Greek sacrificial practices and religion. In his contribution to The Oxford handbook of ancient Greek religion (2015), he takes on what he calls "the Paris School", here again represented by Vernant and Detienne, as well as Walter Burkert. His 2012 monograph on Greek sacrifice, Smoke signals for the gods, also addresses the 
contents and applicability of the Paris school, but does not use this designation. Instead, Naiden refers to Vernant and Detienne and occasionally their collaborators, as well as to Burkert, as forming two distinct schools. ${ }^{17}$

11 Naiden's critique is developed in detail, interacting and scrutinizing various aspects of the model proposed by Vernant and Detienne, both as to the content and evidence. His main points concern the concentration on one particular step of the sacrificial practice, the distribution and consumption of the meat, as well as the neglect of the Near Eastern sacrificial system. Moreover, public sacrifice, according to Naiden, would not have produced enough meat to support the communal meat eating claimed to be essential for the city-state, and he also finds fault with the Paris school ignoring non-sacrificial meat from markets and messes, which is by all means a correct remark. Instead, Naiden's own approach to animal sacrifice emphasizes sacrificial decorum, the beauty and propriety of the ritual as essential elements, all being overlooked by the Paris school (as well as by Burkert and earlier scholars).

A particular genre of the use of the Paris school concept is in fact to contrast it with the work of Walter Burkert, who himself was critical of "die Pariser Schule Jean-Pierre Vernants". ${ }^{18}$ Burkert found that the approach focused on an ahistorical structuralism where the historically given reality was set aside for the sake of the system and its logical structure. For him, such a model may have been good for thinking but it risked curtailing the reality and the facts at hand. Vernant, on the other hand, answered this critique by arguing against Burkert's "retrospective comparatism" that made use of Paleolithic as well as more modern Siberian hunting rituals. ${ }^{19}$ The confrontation between these two approaches resonates also in later scholarship, for example Julia Kindt and Jennifer Larson (see below), as well as in Henk Versnel's discussion of the perception of polytheism in his Coping with the gods (2011). ${ }^{20}$ Jan Bremmer in his chapter on 'Greek normative animal sacrifice' in the Companion to Greek religion from 2007 explicitly confronts the two models, finding them both lacking as to grasping the full complexity and social meaning of the ritual actions. ${ }^{21}$ The fact that the paring of the Paris school with the model of Greek sacrifice proposed by Walter Burkert is frequent in scholarship is not surprising. These two positions are to a certain degree fundamentally different and therefore easy to contrast, but also concur in some aspects, such as their emphasis on the collective nature of sacrifice and the subsequent meat consumption.

13 Many scholars refer to the Paris school as a stop on the road one has to acknowledge but not really actively use. Julia Kind's study Rethinking Greek religion (2012) is one example of this approach. She briefly refers to "the so-called Paris School" as a counterpart to Walter Burkert on the different positions as to the importance of sacrifice and polis religion as an interpretative framework. The Paris school is here seen as an established concept, not demanding any further explanation, but there is no direct attempt to interact with its thoughts, although she discusses Vernant's position on the divine body. ${ }^{22}$ Also Jennifer Larson in her work Understanding Greek religion gives an overview of the shifting paradigms of Greek sacrifice, where the work of the Paris school is presented. ${ }^{23}$ The main features of the sacrificial model are laid out, emphasizing the Paris school's focus on meat-eating and its links to citizenship and sacrifice as a means for communicating with the gods and defining the place of humans in the world, hereby referring to a number of works of the school. Larson also elaborates on the relation to Burkert's model of sacrifice, and points to recent works 
undermining the conclusions of the Paris school. ${ }^{24}$ She takes the Paris school position on sacrifice as an important step in the exploration of Greek religion but it is not used by her as an interpretative tool or model. The Paris school is presented as one influential view of sacrifice, but less so than those of Girard and Burkert, and it is neither used in Larson's subsequent case studies, which is understandable since her purpose is to demonstrate the usefulness of a cognitive framework.

Recent overviews of Greek religion mention the Paris school, but the engagement, positive or critical, is slight. Angelos Chaniotis notes the French school in passing in his contribution on Greek religion to the Oxford Bibliographies Online (2010) when commenting on Louise Bruit Zaidman's and Pauline Schmitt Pantel's study Religion in the ancient Greek city, as well as under the topic "Banquet". Under "Religious mentality", Chaniotis speaks of Vernant and his school, but the Le cuisine du sacrifice is not included among the works treated under the heading 'Sacrifice', which is somewhat surprising. A newly published overview of the archaeology of Greek religion indicates 'the group known as the Paris school' as inaugurating a trend towards the use of structuralism and functionalism in the study of Greek ritual and myth, but does not develop the theme. ${ }^{25}$ In a similar vein, Jennifer Knust and Zsuzsanna Várhelyi in the Introduction to their edited volume Ancient Mediterranean Sacrifice (2011) lay out the theoretical framework of the "Paris School" under the heading 'Sacrifice as cuisine'. The Paris school is presented as one of many models that have been applied and the heterogeneity of the possible approaches is evident from the fact that their Introduction addresses functionalist, social, geographical, chronological as well as particular ritual complexes. One paper in the volume interacts more directly with the theoretical approach of the Paris school; James Rives' chapter on the theology of animal sacrifice in the ancient Greek world, which criticizes Detienne's interpretation of the Orphics and Pythagoreans as being too atemporal and associative in the use of the evidence. ${ }^{26}$

As a contrast to this position, we can note scholars of Greek religion who do not use the term Paris school or the like, but still relate to the work of the members of the school. The 2016 contribution on Greek and Roman sacrifice to the Oxford Bibliographies Online by Fred Naiden and James Rives, mentions the Cuisine of sacrifice, as well as number of works usually counted among the output of the school, but never uses the actual term Paris school or French school. In addition, Daniel Ullucci's comprehensive review of sacrificial scholarship discusses the work by Vernant and Detienne, but does not refer to them as a school. ${ }^{27}$ Finally, some scholars engage with the work of the Paris school as to sacrifice more comprehensively without any explicit use the actual term or one of its equivalences. An example of this approach is Robert Parker. His important handbook On Greek religion (2011) does not mention the Paris school, although he is not alien to school concepts, as he refers to the "myth and ritual" school. ${ }^{28}$ Still, he offers an indepth discussion of the work of Vernant on sacrifice in contrast to that by Burkert. ${ }^{29}$ Here, he raises an interesting point as to the validity of the Hesiodic account for the explanation of Greek animal sacrifice, which forms the foundation of Vernant's analysis of the ritual, and is crucial for that of the Paris school as well. Parker's main point is straightforward, namely if this myth would have been so central to the Greek understanding of animal sacrifice and its execution and meaning, it is surprising that it is not referred to as such in any other Greek source. ${ }^{30}$

16 An avoidance of referring to the Paris school altogether could perhaps also be seen as a sort of critique. Folkert van Straten's monumental Hierà kalá does not explicitly 
mention the Paris school. An implicit reference, as well as an evaluation, may, on the other hand be found in van Straten's description of his approach as "straightforward (some might call it simple-minded)" and to be summarized as "What you see is what you get" ${ }^{31}$ In other instances, the Paris school has apparently not been considered as important enough to be included. For example, a major anthology of theoretical perspectives on sacrifice entitled Understanding religious sacrifice. A Reader edited by J. Carter (2003) provides selections of seminal texts within the field, and contains a chapter on Burkert but none from the works by Vernant and Detienne or their French colleagues.

\section{A Personal Engagement}

17 From this short review, we may conclude that the Paris school (or what we chose to label it) definitely has made an impression on Anglophone scholarship and that its effects span a wide spectrum from adopting, adapting and application, over to criticizing and rejecting as well as a less engaged namedropping. Some scholars use the model developed by Vernant et al. straight off or in a modified version, making room for a more varied spectrum of empirical evidence and also being more aware of chronological distinctions than the original structuralist approach. Others seem to feel compelled to pay lip service to this concept though not deeming it necessary to engage with it on a more constructive level. In outlines of the history of scholarship on Greek religion, the Paris school is an incontournable, a must go to, but after passing this location, one moves on. Still, even those who do not agree will have to acknowledge the existence and (often) the contributions of the Paris school.

A final aspect to comment upon as to the impact of the Paris school are the emotions this concept seems to trigger. Occasionally, there is, somewhat surprisingly, a reaction of irritation among some of those interacting with the Paris school. From an ethnographic point of view, it is interesting to note how certain Anglophone scholars seem to find the work of the Paris school almost as a provocation rather than an intellectual challenge. There is even a sense of taking it personally, either the audacity of an approach that is so blatantly different and individualistic, or the impression that the writers are trying to provide the final truth on Greek religion and sacrifice in particular. The language used can be strong and emotional. Versnel, for example, finds that the followers of the Paris school "feel committed to its creed" and that a different opinion for them would be "blasphemy". ${ }^{32}$ This kind of reaction is evident in some of the reviews of La cuisine as well as The Cuisine, as we saw initially. Occasionally the usually objective academic stance is almost completely discarded. A telling example is Jon Mikalson's review of Paul Cartledge's English translation and slight reworking of Bruit Zaidman's and Schmitt Pantel's Religion in the ancient Greek city in Bryn Mawr Classical Review 2004. Mikalson praises the book for filling an important gap in undergraduate studies of Greek religion and society, but towards the end, he also states that:

...those devoted to the French school will embrace the book, delighted to find their heroes (L.Gernet, J. Rudhardt, J.-P. Vernant, P. Videl[sic.]-Naquet, G. Dumézil, C. Lévi-Strauss, M. Detienne, et autres) hymned throughout. The pervasiveness of their influence is such that even the Greeks begin to look suspiciously like members of the School. 

French and on their "Frenchness" is also intriguing. Versnel speaks of "Gallic and Gallicizing authors". ${ }^{33}$ Naiden repeatedly refers to Vernant and Detienne as "the French scholars' (although Detienne in fact originally was Belgian), contrary to Burkert, whose nationality he does not point out. Bruce Lincoln has developed this kind of contrast between even further. On the one hand, he sees Vernant and Detienne as linked to eating and pleasure when discussing sacrifice and as representing and reflecting a French joie de vivre, while Burkert, on the other, is perceived as associated with killing and guilt, reflecting the post-war German angst. ${ }^{34}$

I would like to end this contribution on a personal note. Due to family related conditions, I spent some time in Paris in the end of the 90 s as a PhD student, which constituted my own exposure to (or initiation into) the Paris school. From 2006-2011 I was fortunate to be in Paris again and then became an associated member of the Centre Louis Gernet, now the Centre ANHIMA. Coming from Sweden and an academic tradition more oriented towards Great Britain and the US, and formerly Germany, the French mode of approaching scholarship was completely different or even alien to me, to begin with. The theoretical level guiding and initiating any research enquiry at the seminars of the Centre was very dissimilar from my own more empirically grounded approach. Still, or perhaps because of these circumstances, my meeting with this environment was tremendously stimulating as it offered a very high level of abstraction and creativeness, and a detailed knowledge of the ancient material, be it an image or a text, as well as a consisted theoretical approach. In short, a "school" in its most positive sense.

But there was also, I found, especially among the PhD students, sometimes an unawareness of them being within a school and that there were other approaches to the study of the ancient world apart from that of the "Paris school". Occasionally, I have to admit that there was even a lack of realization that structuralism is a tool invented by modern scholars and not an inherent ancient way of organizing and understanding the world, neither one that is accepted as valid by all modern scholars. In a sense, I was glad I was an outsider or I might have been surprised or even chocked when meeting the wider world of international scholarship on Greek religion outside that of the confines of the Paris school. Perhaps we are to understand some the reactions by Anglophone scholars it this light. Finally, I gladly admit to my own work on Greek sacrifice being inspired by The cuisine of sacrifice, and especially the usefulness of the model for exploring the role and function of sacrificial rituals. ${ }^{35}$ Consistency is never easy, however. When writing this contribution, I discovered that I in my own texts have used both "the so-called Paris school" and "the French school". However, as we say in Sweden, "a beloved child is called by many different names". 


\section{BIBLIOGRAPHY}

Blakely S. (2014), "Religion, Greek, Archaeology of," in Smith C. ed., Encyclopedia of Global Archaeology, New York, p. 6276-6284.

Bremmer J. (1985), "Before the Animal Liberation Front," CR 35, p. 312-313.

- (2007), "Greek Normative Sacrifice," in Ogden D. ed., A Companion to Greek Religion, Malden, p. 132-144.

Burkert W. (1977), Griechische Religion der archaischen und klassichen Epoche, Stuttgart.

- (1985), Greek religion. Archaic and Classical, translated by J. Raffan, Oxford.

Buxton R.G.A. (1981a), "Review of La cuisine du sacrifice en pays grec by Marcel Detienne and JeanPierre Vernant," CR 31, p. 131.

- (1981b), "Introduction," in Gordon R.L. ed., Myth, Religion and Society. Structuralist Essays by M. Detienne, L. Gernet, J.-P. Vernant and P. Vidal-Naquet, Cambridge, p. ix-xvii.

Carter J. ed. (2003), Understanding Religious Sacrifice. A Reader, New York.

Chaniotis A. (2010), “Religion, Greek,” in Oxford Bibliographies Online.

Detienne M. and Vernant J.-P. eds. (1979), La cuisine du sacrifice en pays grec, Paris.

- eds. (1989), The Cuisine Sacrifice Among the Greeks, translated by P. Wissing, Chicago-London.

Ekroth G. (2007), “Meat in Ancient Greece: Sacrificial, Sacred or Secular?," Food \& History 5, p. 249-272.

- (2008), "Burnt, Cooked or Raw? Divine and Human Culinary Desires at Greek Animal Sacrifice," in Stavrianopoulou E., Michaels A. and Ambos C. eds., Transformations in Sacrificial Practices. From Antiquity to the Modern Times. Proceedings of an International Colloquium, Heidelberg, 12-14 July 2006, Heidelberg, Berlin, p. 87-111.

- (2017), "Holocaustic sacrifices in ancient Greek religion: Some comments on practice and theory," in Bielawski K. ed., Animal Sacrifice in Ancient Greece. Proceedings of the First International Workshops in Kraków, Warsaw, p. 45-66.

- (2019), "Why does Zeus care about burnt thighbones from sheep? Defining the divine and structuring the world through animal sacrifice in ancient Greece," History of Religions 53-3, p. 225-250.

Finney P.C. (1994), "Review of The Cuisine of Sacrifice among the Greeks," Journal of Early Christian Studies 2, p. 224-226.

Georgoudi S. (2010), "Sacrificing to the gods: Ancient evidence and modern interpretation," in Bremmer J. and Erskine A. eds., The Gods of Ancient Greece: Identities and Transformations, Edinburgh, p. 92-105.

Kindt J. (2012), Rethinking Greek Religion, Cambridge.

Knust J. and Várhelyi Z. eds., (2011), Ancient Mediterranean Sacrifice, Cambridge.

Kritzman D.L. et al. (2006), The Columbia History of 20th Century French Thought, New York.

Larson J. (2016), Understanding Greek Religion: A Cognitive Approach, London. 
Lincoln B. (2012), “From Bergaigne to Meuli," in Faraone C. A. and Naiden F. eds., Greek and Roman Animal Sacrifice: Ancient Victims, Modern Observers, Cambridge, p. 13-31.

Meslin M. (1982), "Recent French Research in the history of religions," History of Religions 21, p. 294-304.

Mikalson J. (2004), "Review of L.B. Zaidman and P. Schmitt Pantel, Religion in the Ancient Greek City. Translated by Paul Cartledge. Cambridge," BMCRev 04.06.13.

Murray O. (2007), “Jean-Pierre Vernant: Resistance Leader and Hellenist,” The Independent, 11 January.

Naiden F. (2015), "Sacrifice," in Eidinow E. and Kindt J. eds., The Oxford Handbook of Ancient Greek Religion, Oxford, p. 465-475.

Naiden F. and Rives J. (2016), "Sacrifice," in Oxford Bibliographies Online.

Osborne R. (2016), “Sacrificial theologies," in Eidinow E., Kindt J. and Osborne R. eds., Theologies of Ancient Greek Religion, Cambridge, p. 233-248.

Parker R. (1979), “Greek religion,” CR 29, p. 86-88.

- (2011), On Greek Religion, Oxford.

Peirce S. (1993), “Death, revelry, and 'thysia'," ClAnt 12, p. 219-266.

Petropoulou A. (2008), Animal Sacrifice in Ancient Greek Religion, Judaism, and Christianity 100 BC - 200 $A D$, Oxford.

Pollard J. (1981), "Review of La cuisine du sacrifice en pays grec by M. Detienne and J.-P. Vernant," JHS 101, p. 184-185.

Poplin F. (1989), 'Matière, animal, homme, esprit. Introduction à l'animal dans les pratiques religieuses', in Meniel P. ed., Animal et pratiques religieuses : les manifestations matérielles, Anthropozoologica N.S. 3, p. 13-21.

Rives J. (2011), "Theology of animal sacrifice in the ancient Greek world," in Knust J. and Várhelyi Z. eds., Ancient Mediterranean Sacrifice, Cambridge, p. 187-202.

Ullucci D. (2015), "Sacrifice in the ancient Mediterranean: recent and current research," Currents in Biblical Research 13, p. 388-439.

Van Straten F. (1995), Hierà kalá. Images of Animal Sacrifice in Archaic and Classical Greece, Leiden.

Vernant J.-P. (1991), "Greek religion, ancient religions," in Vernant J.-P., Mortals and Immortals Collected Essays, ed. F. Zeitlin, Princeton, p. 269-289.

Versnel H.S. (2011), Coping with the Gods: Wayward Readings in Greek Theology, Leiden.

Vidal-Naquet P. (2006), “Antiquity revisited," in Kritzman D.L. et al., The Columbia History of 20th Century French Thought, New York, p. 143-149.

Vlassopoulos K. (2007), Unthinking the Greek polis, Cambridge.

Zeitlin F. (1991), “Introduction," in Vernant J.-P., Mortals and Immortals - Collected Essays, Princeton, p. 3-24. 


\section{NOTES}

1. Definitions of 'school' in the Oxford English Dictionary I.8: "Also with capital initial. Frequently with modifying word or phrase. The body of people taught by a particular philosopher, scientist, artist, etc. Hence more widely: a group of people who follow or are influenced by the teaching of a particular person, or who share similar principles, ideas, or methods."

2. Other aspects of the Paris school can also be found in scholarship, such as their emphasis on the importance of the polis in the study of ancient history, see, for example, Vlassopoulos 2007, p. 66.

3. Buxton, 1981a, p. 31.

4. Meslin 1982, p. 300-301.

5. Pollard 1981, p. 184-185.

6. Finney 1994, p. 224-226.

7. See the review by Jan Bremmer (1985) of the English translation published in 1983.

8. Reviews in English appeared only after the English translation with the exception of Robert Parker's contribution (1979).

9. I leave aside Francophone scholarship by non-Paris school members, which is a topic of interest by itself. For a recent evaluation of the approach by one of its own members including pointing to some of its weaknesses, such as a select use of the evidence and an unwillingness to interact with other models than thysia and with other sacrificial matters than those deriving from animals, see Georgoudi 2010.

10. Buxton 1981b, ix-xvii, esp. p. $x$.

11. Vidal-Naquet 2006, p. 147, who underlines Vernant's seminal contribution, but comments that the heterogeneous nature of the members led to that no orthodoxy arose but also to personal conflicts causing the departures of certain members.

12. See in particular the comments by Froma Zeitlin in the introduction to Mortals and immortals (1991) and the obituary by Oswyn Murray in the Independent, January 11, 2007.

13. Peirce 1993, p. 220-222.

14. Petropoulou 2008, p. 13-14.

15. Petropoulou 2008, p. 39, n. 27; Poplin 1989.

16. For her overall approach, see Petropoulou 2008, p. 26-31.

17. Naiden 2012, p. 14. That there is a Paris school is universally accepted, the Burkert school perhaps less so. Versnel $(2011$, p. 35$)$ finds that there is no such thing as a 'school' of Burkert, due to his diversity as a scholar and that his theoretical framework cannot be housed under such a term, a statement that allows for a generous reading of Burkert but a more restricted one for the Paris school followers.

18. Burkert 1977, p. 25-26 and p. 333 (German original) and Burkert 1985, p. 3-4 and p. 217 (English translation), referring to Vernant's Mythe et société en Grèce ancienne (=> Mythe et verité en Grèce ancienne) (1974).

19. For example, in his inaugural lecture at the Collège de France published in 1977, and in English in 1991 as 'Greek religion, ancient religions', p. 269-289, esp. p. 279 (Vernant 1991).

20. Versnel 2011, esp. p. 26 and 35 with n. 41. 
21. Bremmer 2007.

22. Kindt 2012, p. 3, p. 64 (with n. 47) and p. 191; for Vernant and the divine body, see p. 157-159.

23. Larson 2016, p. 202-203.

24. Larson 2016, p. 203, in particular the work by G. Ekroth on the zooarchaeological evidence and F. Naiden's criticism of functionalist analyses.

25. Blakely 2014.

26. Rives 2011, p. 191-192.

27. Ullucci 2015, p. 395-397.

28. Parker 2011, p. 23.

29. Parker 2011, p. 128-131. In his section on Greek gods, Parker also discusses what he labels the "structuralist approach" (2011, p. 84-97).

30. Parker 2011, p. 140-141; see also Osborne 2016, p. 236.

31. Van Straten 1995, p. 5.

32. Versnel 2011.

33. Versnel 2011, p. 35.

34. Lincoln 2012, p. 13-31.

35. See, for example, Ekroth 2007, 2008, 2017 and 2019.

\section{ABSTRACTS}

The denomination "school" in academic contexts carries with it a certain ambiguity. It can evoke a stimulating and innovative environment with a positive synergy between its members, but also a self-sufficient and almost complacent academic setting mainly concerned with preserving its own worldview. From this starting point, my contribution will reflect on the impact of the École de Paris within the field of Anglophone research on Greek religion and especially on animal sacrifice. Focus lies on how has the concept of a "Paris school" been handled within the study of Greek religion and what position it occupies among scholars working in this field. Four overlapping positions can be distinguished: (1) naming and using the Paris school as a theoretical approach, (2) critiques, which is also a form of interaction, (3) naming and referring in passing without an in depth engagement, and (4) studies on Greek sacrifice which do not use the term or comment on the Paris school.

La notion «d'école» recèle une certaine ambiguïté dans le domaine académique. Elle peut évoquer un environnement stimulant et innovant qui permet d'instaurer une synergie positive entre ses membres, mais aussi un cercle académique auto-suffisant et presque complaisant préoccupé avant tout de maintenir ses positions. C'est en prenant en compte cette ambiguïté que cet article réfléchit sur l'impact de l'École de Paris dans le champ de la recherche anglophone sur la religion grecque, et plus particulièrement sur le sacrifice animal. Il se concentre sur la manière dont le concept «École de Paris » a été utilisé dans l'étude de la religion grecque et quelle place il occupe parmi les chercheurs dans ce domaine. On peut distinguer quatre positions qui se 
recouvrent partiellement: (1) nommer et utiliser l'École de Paris comme une approche théorique; (2) la critiquer, ce qui est une forme d'interaction; (3) la nommer et l'utiliser « en passant » sans implication profonde ; 4 ) ne pas la nommer ni ne faire aucun commentaire.

INDEX

Mots-clés: sacrifice animal, viande, Jean-Pierre Vernant, Marcel Detienne, Walter Burkert, structuralisme

Keywords: animal sacrifice, meat, Vernant, Detienne, Burkert, structuralism

\section{AUTHOR}

GUNNEL EKROTH

Uppsala University 